\title{
The Effective Power of Music in Africa
}

\author{
Celestine Chukwuemeka Mbaegbu \\ Department of Philosophy, Nnamdi Azikiwe University, Awka, Nigeria \\ Email: ezeakilebuchi@gmail.com
}

Received 18 November 2014; accepted 23 March 2015; published 26 March 2015

Copyright (C) 2015 by author and Scientific Research Publishing Inc.

This work is licensed under the Creative Commons Attribution International License (CC BY).

http://creativecommons.org/licenses/by/4.0/

(c) (i) Open Access

\begin{abstract}
This article investigates the role of music in Africa. The study is primarily motivated by the fact that music plays an indispensable role in the being of Africans at work, in politics, in their socioeconomic engagements, in religious worship, integral development, in their moral life, etc. The primary objective therefore is to ascertain the influence of music with regard to the integral development of the Africans and the overall acknowledgment of this indispensable role on the active and meaningful behavior of Africans. Using the methods of phenomenology and analysis, the findings reveal that Africans are music lovers and that music features as an indispensable handmaid of any meaningful behavior and sustainability of the being of any African person whether young or old.
\end{abstract}

\section{Keywords}

\section{Music, African Music, African Morality}

\section{Introduction}

Black Africa shows certain cultural unity. This is the consequences of analogous existential experiences of life in an isolated and difficult environment. This phenomenon has slowly produced a unified African world distinct from and comparable with Western and Asian worlds. And with the end of the Second World War the African wishes to become conscious of himself as a being in the African world and to live with that consciousness, and consequently, his culture, his being and total environment have become very significant to him.

There is now African philosophy quite distinct from Western, Indian, Asian and even American philosophy. We also talk of African Art, Literature, Poetry, Music, etc. In short, since the end of the cold war, Africans are determined that they are "black and proud of it" and are also determined to show the world that Africa is not some sort of blank sheet in the history of world's contribution to rich cultural values and heritage, and according to Cesaire (1972: p. 76) "its values are values that can still make an important contribution to the world".

It is the contention of the author of this article that African music is another area of Africa's great contribu- 
tions to world civilization and recreational facilities, and that Africans are notoriously music lovers. Music permeates into all the various aspects of their lives. Various African writers have highlighted this aspect of the cultural life of the Africans by saying that music has rooted itself in African culture so much so that it has become part and parcel of their everyday life. Some maintain that more than any other continent in the world the African is jovial, light hearted, emotional and sensitive to music. Little wonder his manual work, his recreational periods, his suffering moments, etc. are punctuated with music. For instance, at the birth of a child he/she is received into the community amidst dancing, rejoicing and songs of jubilation. The same music features in driving and in moments of sorrows and joys. For instance, the ceremony of a genius in any spheres of human endeavors, at funerals, launchings of all sorts, initiation ceremonies, etc. even at the battle fields including the field of soccer, music dominates the life of the African. In almost all the denominational churches and even in the Catholic Church music has become an inseparable handmaid of worship. Put simply, African music is one of the cultural characteristics that make the African who he is as a distinct cultural being in the world, for it binds Africans together and gives them common characteristics.

In this article, therefore, having established that music is not alien or extraneous to the Africans but part of their culture, we shall address ourselves to the nature and role of music in the integral development of Africans especially in their social life, in politics, in guiding his moral, religious and integral development of the African person. Secondly, we shall critically examine as much as possible different types of African music but not in isolation with the roles they play in African society. Thirdly, we shall try to establish the basis of African morality, that is to say, in African society what makes a given act right or wrong, and finally we shall see if there is any relationship between African music and morality.

\section{Definition of Terms}

To avoid ambiguity and for the sake of clarity let us define those terms that are pertinent to this article. The "African", the object of inquiry in this article is the black African mainly south of the Sahara without prejudice to the Negroid race scattered all over the globe.

\subsection{Music: A Formal Definition}

The term music means sounds made by playing instruments or singing. Chambers Universal Learners Dictionary defines music as the art of arranging and combining tones or sounds in order and often together to make a complete unit which has beauty of form and which is intended to communicate some emotion. For Degmecic, Pozgain, \& Filakov (2005: p. 229), "music is the special form of flexible abstract thinking, which enables us to use all kinds of configurations and schemes in our developmental stages in the creative and integrative purposes".

\subsection{African Music}

Our brief definition so far of the nature or concept of music and the African is to introduce us to the understanding of African music. African music on the other hand is unique in itself. It is any sounds produced by playing indigenous African instruments like the wooden drum Ekwe, and other major and minor wind instruments like the Ogene, the $U d u$, the Flutes, and the Oyo, etc. African music also includes any sound produced by the Africans with their mouths popularly known as the "African Voices". The most important thing about any type of African music is that it has beauty of form and is intended to communicate some emotion.

\subsection{African Morality}

This deals on what is good or bad for the African and determinants of such goodness and badness of actions. The temptation to elaboration will be resisted here mainly because of the nature of this article and more so because such a topic has never enjoyed any universally accepted answer. African morality and its basis for one thing is still debatable or controversial for an academic enterprise, it has not enjoyed long history, tradition and authority. Consequently no definition or view has been tested by line of years of scholarship.

In this article we shall insist that African understanding of morality is inseparable from their world view which includes their concept of the Supreme Being, origin and nature of the universe, the relationship between the supreme force and the forces below him beginning from the Arch patriarchs down to the inanimate forces. The traditional African has a notion of a Supreme Force who according to Temples is Nwine Bukomo Bwandi 
that is, he who has force, power, in himself. He gives existence, power, survival and increase to other forces. Hence, the different names assigned to Him, namely, Chukwu the ultimate force, Chineke, or Chi-Onye Okike or Eke-Kere Uwa, the maker of the world. For the Africans therefore; the world neither evolved from any known stuff nor was it as a result of any cataclysm or concatenation of already existing things but it was made in time. This point was already recorded by different African scholars. Mbiti (1975: p. 32) points to this fact when he observes that "it is generally believed all over Africa that the universe was created. The creator of the universe is God... God is, therefore, the explanation for the origin of the universe which consists of both visible and invisible realities".

\section{The Role and Inter-Relatedness of African Music and Morality}

Since the African postulates a Supreme Being for the explanation of created forces let us establish the hierarchy and interaction of these uncreated and created forces as a path to the understanding of African morality. Mbiti (1985: pp. 205-206) lends his voice here by arguing that:

God is the creator and hence the parent of mankind, and holds the highest position so that he is the final point of reference and appeal. Beneath him are the divinities and spirits, which are more powerful than man and some of which were founders of different societies. Next come the living dead... Among human being the hierarchy includes kings, rulers, and rain-makers.

Contrary to the prejudices of the white man, the word morality for the black man has its significance or value. An action is considered right or wrong and as such, Basden (1966: p. 34) argues that "in almost all the African societies a clearly defined code of morals exist and infringements of these laws may lead to severe penalties being inflicted, and cases are known where infidelity on the part of a wife has been punished by the torture and death of both offenders".

Hence we can conclude that the existence of sanctions, laws, hierarchy of forces, authority and above all societal consciousness engender a sense of morality among the Africans. The presence of sanction does not mean the absence of a moral worth because sanctions are indispensable in a traditional society. Like any other race therefore the African or the Black man is inescapably groping with the realities of moral problems.

Having established that the African has sense of the "good" and the "bad" let us address ourselves to what "good", and "bad", "right", and "wrong", mean to the Africans and eventually establish the basis on which the African man makes value judgments.

As we have already established that African moral judgments are principally based on their world view; good and bad in African society therefore depend on their conception of the universe and his place in it. Such moral value judgments are made with particular reference to the practical realities of life of the individual and the society. Consequently Nwala (1985: p. 143) correctly observes that "the Greek sophists were right when they argued that morality is a social product, it is conventional, and made by men".

To the African, force, life or being is the Suтmum bonum or highest value. Life is of supreme importance. The Igbo say that life is of supreme importance: (Ndu bu Isi). This important belief in the primary value of life is reflected both in the cosmological order and in the day to day life and activities of the African people. In their daily life one sees the importance attached to life especially in marriage, death and funeral ceremonies. It is reflected in their prayer life, in their sacrifices, in their possession of charms and amulets and in the taping of the vital forces of another. When a man sneezes, both he and those around him would wish that his life be preserved.

In such institutions as death and marriage, one sees the supreme importance attached to $N d u$ (life). To the African life is a never ending process and its perpetuation is the goal of all activities and aspirations. Kagame is more exact about this when he writes that African philosophy knows the problem of immortality and deathlessness and has recognized and solved it long ago. For the Africans the living person has the innate wish to exist for ever. But since death is an unavoidable limit situation, he prolongs his existence as a living person in his descendants knowing full well that he is constructed for reproduction, he is put into the world in order to perpetuate himself in order to leave living heirs behind him thereby averting the worst evil that can befall a man, an evil so terrible that it tantamount to a curse. Indeed, in Africa the worst of evils, the irremediable catastrophe falls on the dead ancestors who for the whole time of their infinite deathlessness missed the goal of their existence, which is to perpetuate themselves through reproduction in the living person. The point being expressed here is that life is of primary value and that everything is concentrated on the precious existence of the living, in 
which the life that was transmitted to them from their ancestors is carried on. Life in African conception is the dynamic quality of material and human existence. Life is also existence itself, and existence could take various forms, either material, spiritual, or pure spirits. Death in this world is seen as the dissolution of the flesh during which the spirit enters a separate existence maintaining the life force of the individual in another sphere or form of existence.

An individual has force or life, any social group, the family, the village, etc. has its own existence and its perpetuation is the ambition of both the individual and the group. There is no question of rugged individualism in African society; the individual exists because he finds himself in a society. The African is essentially man-in community. It is the community which makes the individual, not the other way round, a point made by Mbiti (1975: p. 108) in defining the becoming of an individual in African culture in this aphorism: "I am because we are, and since we are, therefore I am".

From the ongoing discussions, it could be deduced that in African society an action is right or wrong in so far as it increases or diminishes the vital force of both the created and the uncreated forces except when the forces diminished are under the disposal of man because their sole purpose is to increase the vital force of man. African morality is at once dynamic rather than static. The good is what the society wants and the bad is abhorred. Thus African morality is at once, metaphysical, ethical and juridical.

\section{Types and Roles of African Music}

Mother Africa can be said to be a land of diverse music, and any type of African music plays a vital role, hence the existence of such, because Africans believe that the purpose of anything give meaning and existence to the thing itself. Mother Africa hosts three categories of music among which are traditional, popular and classical. Traditional music includes all traditional or folk music that serve as media of expression of African people's culture and according to Nwamara (2009: p. 534):

They are being transmitted orally from one generation to another. In its transmission process, allowances are made for each generation to make selections and variations from the original composition without destroying its tone of continuity. The music and its practitioners are found in greater number in the rural areas. Their composers are not known because the music/s is/are communally owned.

Then there is the popular music generally referred to as "pop" music which is a contemporaneous music, which appeals to a mass audience and is dance oriented. Popular music found in Africa is coeval and Western. The genres of popular music in Africa fall under three categories: the derivatives of traditional music, e.g. the Nigerian apala, sakara, akuko n'egwu, and dadakuada; Those that reflect interaction between local and Western/ Arabic musical cultures like highlife, juju, fuji and ajasco; The Western popular mainstream and those that result from interaction between Africa and New World Cultures: the Afro-American Forms-reggae, raga rap, Afro-beat or Afro-rock, soul, Congo music, disco, electronic and jazz-rock, and Ozzidi. The last of the three classes of music in Africa is the Classical Music. Classical here means all written music composed in accordance with certain universally accepted conventions and rules. In more recent times precisely with the advent of democracy as a political ideology in Africa, a new class of music springs up which can be described as Political music. Political music falls within the three classes of music in Africa and can appear in any of the three. The primary determinant here is the lyrics/text of the song. Consequently, Nwamara: (2009: p. 535) asserts that "political music exists in various forms as "one track music in an album, a complete album, electioneering campaign song, jingles, state or town or party songs/anthems, rally songs, and spontaneous compositions".

One of the types of African music is the signaling type. This is seen in different categories of African peoples: children, boys, girls, men and women. Almost at the tail end of the third millennium, Nketia (1975: p. 23) writes on this type of music as follows: "When children assist in the economic activities of their parents or are given special responsibilities, such as looking after flocks, they may be encouraged to play flutes for their own enjoyment, for giving signals to their companions, or for guiding their flock".

Among the adult folk, when a man dies the big wooden drum (Ikolo) bellows, signaling the death of someone and in a space of time, listening to it the name of the dead could be heard. In this, the signaling type of music serves the role of disseminating information in most African societies. For the adult African, music is the sole of life. It permeates all his daily activities ranging from domestic affairs like grinding snuff, pounding, building hunting, ploughing, tapping fishing, etc; all grounded on the fact that not only manual labor that puts the fruits of the field at man's disposal. Sowing and reaping are only parts of human activity. Man must do more than sow 
and reap; speech and song must be added, for it is the combination of words and songs and voices that make the seed corn to germinate and grow, the cows go in calf and give milk, the hymns of praise sung by the sorcerer while the goldsmith is working the gold completes the work and makes it a masterpiece. Thus all the activities of men, and all movements in nature among the African are accompanied with songs. Indeed, all change; all production and generation are believed to be effected through the word and music.

We have recreational, entertainment and aesthetic enjoyment type like the Mkpokiti (acrobatic music of Nigeria). Among the types of African music are the religious music, war music, praise music, highlife music, Afrobeat music, folk music, etc.

The role of music in African society depends on the type of music. Religious music inspires the worshippers to express their loyalty to the deity. African religious hymns have triple functions: Reparation, Thanksgiving and Petition. Apart from these, most religious hymns teach good morals, underlying the necessity of virtuous deeds and denouncing evil acts. By this function, African composers particularly composers of highlife and philosophical tunes serve to re-direct the straying society through their music, for example, Mike Ejeagha's Onye Mkpesa and Celestine Ukwu's Asili Ajoka. Sunny Okoson's is today both philosophical and religious but before now his appearances over the telecast were in no way commendable, etc.

On the other hand there are some African musicians, who, due to outside influence, either American or European have turned their brand of music as medium for propagating and disseminating doctrines of licentiousness, sexual liberalism and moral indifference. Such brands of music were exemplified in late Fela's Afro band and his lover girls.

Apart from religious music, Nettle (1956: pp. 6-7) adds that:

Africans have war music sung during war periods and at the war front. The role of music during periods of war is to solicit supernatural assistance, ensure success while that sung by soldiers at war fronts, encourages soldiers to move into the battle field confident that victory is theirs. Among the [Igbo] of Nigeria, there is incantation which emboldens their spirit and summons them to action. The [Igbo] people are like the elephant.

In folk tales or story telling brands, the pre-modern Africans equally indulged in music to entertain and recreate themselves. The highlife brand with its philosophical import relaxes the soul, gladdens the heart, upholding moral behavior and opens the eyes of the Africans to the goings-on in the African universe.

In political life of the African, music is not relegated to the background. There are praise songs and music to get the better part of the leaders of various communities and various state governors including any constituted authority. Wealthy men and craftsmen not excluded.

I can wind my mind back to see how I was singing the praises of my grandfather as he climbed the tallest palm tree in my town which everybody feared to climb. Agordoh (1985: p. 15) also records the following functions of music among the people of Africa, "music is used as a social control, and there is music to criticize those in authority. For example in Benin Republic, there are 'songs of allusion' which are topical songs of current events of interest and gossip, and to perpetuate knowledge".

For Azubike O. Ifionu, music functions as a vehicle of social control and integration, and as a means of validating social status and institutions and finally, as an agent of continuity and stability.

African music has functions for, social control, social integration, signaling, for dissemination of information, for inspiring, for entertainment, as means of recreation, for encouragement, for solicitation of supernatural assistance, for reparation and thanksgiving. Others teach good morals underlining the necessity of virtuous living and denouncing wrong deeds. African music is therefore a rich cultural value or heritage and through that Africans anywhere on the globe are easily identified. African music is part of the essence of the African.

\section{Moral Signposts in African Music}

Having seen the nature, types and the role of African music in the African universe, let us examine the inter-relatedness of African music and morality. So the problema criticum (critical problem) here is: Has African music any influence on the moral life of the Africans? Inversely, we shall see how African conception of morality permeates or influences all the aspects of African music. It has been observed that both act as a check and balance to each other. While morality sets the pace, African music upholds good morals and denounces some bad ones. We intend to maintain here that one of the values that mechanically and unconsciously make the African people do the right and avoid the wrong is African music. Other values according to Ade-Adegbola (1983: p. 171) include "their religious beliefs, practices and taboos, their we-feeling and desire for group solidarity, the 
experiences, common sense and conscience of the individual, the influence of proverbs, wise sayings, folk tales and stories some of which may be based on custom, experience, we-feeling religious ideals".

One thing about African music is that it is never devoid of any values; it extols, exonerates or justifies some good qualities, condemn or blame the bad. In some cases it makes value judgments, stipulates or pinpoints moral evil and injustices in various regions of Africa. Going further to elaborate the role of African music Asigbo (2012: p. 690) maintains that "to the African however, music making goes beyond mere exhibition of virtues hence it is seen as vehicle for moral preachment as well as a means to connect to the great beyond". The African see music as a weapon for correcting moral deviants and as a medium through which a lost society can be shocked back to life. Consequently, some classes of African music, namely traditional can therefore be regarded as a herald or vanguard of moral change because African folk musicians make conscious attempt to use their brand of music to influence behavior. "Little wonder, Moore (1982: p. 18) contends that "with music, I create change. I seek it. So really, I am using music as a weapon". Music in Africa is a call to service, a medium through which an earring and ignorant can be shocked back to awareness, inculcate and re-enforce social norms and values while some music forms in Africa especially the parabasis, which is usually the end of the story, witnesses the musicians telling the moral of the story as well as warning and advising the audience on future courses of action. A critical look at the forms or arrangement of parts of African Traditional music will reveal instantly that they are deliberately arranged to enhance the teaching of morals.

Thus, Asigbo (2012: p. 692) insists that once a society has decided on its set of moral codes, "it is usually the artist's sacred mandate to act as the watchdog of those codes. It is equally the artists' prerogative to act as heralds for changing of those codes that have outlived their usefulness. Africa always sees in her artists, voices of reason and heralds of change who can look at people and tell them their sins to their face". Soyinka (1976: pp. 12-13) also lends his voice to the imperative role of African artists when he reiterates in no uncertain terms that "where the writer in his own society can no longer function as a conscience, he must recognize that his choice lies between denying himself totally or withdrawing to the position of a chronicler and post mortem surgeon... The artist has always functioned in African society as a voice of vision in his own time". A comparative analysis of many African traditional artists' songs will immediately reveal this obsession of African artists devoted to the moral well being of their continent. One can rightly say that African society as presently constituted and run is in dire need of ennobling qualities. This is because; any society without a sound moral basis can only flounder in the void of moral stasis. To move further therefore, Africans must constantly be reminded that it is good to be good; that we must shun all acts that promote nepotism and clannishness and most importantly, that we must become our brother's keeper. These are the lessons which all true African artists are morally obliged to inculcate into the citizens of the world. Based on hermeneutical and phenomenological revelations our deductions are clear when we remember the contribution of Asigbo (2012: p. 696) when he highlights "that contrary to popular opinion... Oral performance can indeed redirect an earring society, be a tool for moral and ethical regeneration and in fact, serve as a vanguard for socio-cultural change."

Often times African music re-echoes the state of injustice done to any oppressed section of the Africans, either by the white man or by some wretched and dictatorial African leaders. Some call for unity of the Black race in order to fight an oppressed, unaccepted and dehumanizing system like Apartheid as it was practiced in South Africa. A practical example is: Sunny Okoson's, "Africa is now or never", and "Africa must unite". One remembers also Neli Uchendu's Africa must survive". All these are the good inherent in African music, songs and folk-tales of the mother Africa. It is interesting and heart emboldening to listen to Mike Ejeagha, late Celestine $U k w u$ and his philosophers national. What is more if you listen to most of late Stephen Osadebe's highlife music? They all act as vehicle for dissemination of good morals.

Among the Igbo of Nigeria, for instance, there are satirical songs of insult. These are effective means of negative sanctions in the society. What the African society sanctions as morally good are expressed in music. And when individuals excel in good morals or in any virtue he/she is musically praised, honored. For instance among the Efik, brevity or courage is musically extolled. Consequently some African musicians today act as catalyst in facilitating, encouraging or denouncing or helping to pinpoint areas of moral decadence in African society and some go to the extent of giving possible solutions to so many social ills like structural injustice in various African countries.

At this juncture one need not overlook the negative aspects of some African music coming from some Europeanized or corrupt African musicians who, through their brand of music sale to the public immoral languages and parade themselves nude. Thanks to the African conception of morality which acts as a check to some Afri- 
can music. African music upholds African morality and the same African music which upholds morality do contain some elements that derogates or instill bad morals in African society. This is a point that need not be doubted that African conception of morality influences African music.

In Igbo land for instance dances are grouped according to sexes particularly in areas where it is clear that things are likely to go wrong. This shows that their understanding of morality influences their types of music and dances.

The Igbo have a high regard for chastity. For them it is a virtue and for that reason in their musical symposia or shows they would cover those areas they consider immoral when exposed to the public eyes and in some areas for some reason of good morals, boys are separated from girls; men from women. Indeed what is morally accepted in African society is venerably reflected in the musical performances of the African man.

The masquerade displays in Igbo society is a case in point. Women do not participate in masquerade display, that is, Iti Mmanwu, for the society forbids them because it is an activity between the founders and custodians of various clans, namely, the Arch-patriarchs and the ancestors respectively.

In traditional African society people's notion of morality go a long way to influence their music. It is therefore not usual for the African to make merry for their achievements especially when such goals are attained with their physical ability but they insist on justice and fairness in such contests. For this reason, in wrestling competitions people face their equals and it is unusual in African society for a man to face a woman in wrestling competition. African traditional society in all its numerous social activities observes certain ethics. Ifionu remarked that in wrestling competition each group of competitors has his own Ekere Mgba drumming for wrestling in which the players, especially the flutist, call the praise names of the competitors and encourage them to excel. The competitors observe certain wrestling ethics the most important of which is Odika Onye Puta Mgba, Odika Ya Agba $\mathrm{Ya}$ (if a challenger comes out, another challenger of equal ability will come out). This calling of competitors in the order of equality, sex and strength is to ensure justice and fairness or equity with the consequent peace, unity and love among the particular clan or kindred concerned.

\section{Conclusion}

It must be stressed that there is a mutual complementarity between African music and morality. Today African music is invaded from all angles by western influences. There are noticeable cultural borrowing and lending among different nations of the world. This is clearly brought out in these words of Agu (2001: p. 224) as he laments that:

Some music types in the rural communities have lost their contextual usage, concepts and affect, and are now performed more on prestige and entertainment values. It is also true that most of the rural... Audiences have lost trend of the socio-cultural and religious implications, meaning, and story-interests embedded in most performances, symbolic costumes, instruments, performance situations, timing and venues. Nevertheless, what has been happening is development in innovative continuity since the new genres still remain identifiable with the original genres whose contextual usage, meaning and significance have neither been altered nor effaced.

Despite these modern changes brought about by foreign influences, Africa stands out as a continent to show that a people can appropriate modern values, modern technology and modern forms of organization without abandoning their traditional culture, and that modernity can be assimilated to a non-European culture without destroying it. In African as well as any other races in the world, music is always therapeutic, emboldening, captivating, inspiring by bringing one nearer to the Divine. This transformational, fundamentally dynamic and ecstatic character and qualitative role of music, especially the Liturgical music, so emboldens Achike (2011: p. 224) to assert in no uncertain terms the view that:

When the word becomes music, there is involved, perceptible illustration, incarnation or taking on flesh, attraction of pre-rational and supra-rational powers, a drawing upon the hidden resonance of creation, a discovery of the song which lies at the basis of all things. And so this becoming music is itself the very turning point in the movement: it involves not only the word becoming flesh, but simultaneously the flesh becoming spirit. Brass and wood become sound; what is unconscious and unsettled becomes orderly and meaningful resonance.

African music as a source of aesthetic education in African classrooms is very important because Onyiuke (2001: p. 51) is of the same view with some African music scholars that:

It has been emphasized that the child who is not sufficiently exposed to music in the elementary years may never realize his/her full potential in this area. To encourage these early experiences in musicianship, and also 
to dispel the notion that classroom musical instruments are necessary sophisticated and expensive, that there is need for improvising and utilizing homemade instruments.

For Plato, music is a moral law and it gives a soul to the universe, wings to the mind, flight to the imagination, a charm to sadness, gaiety and life to everything. It is the essence of order and leads to all that is good, just and beautiful, of which it is the invisible but nevertheless dazzling, passionate and eternal forms. The Africans live and move as if something is lacking in their way of being unless music is involved. Among the Africans, life for both the young and the old becomes more meaningful and gainfully sustained by music.

The relationship between African music and morality has been a healthy one, which is both symbiotic and complementary. In this healthy alliance each feeds the other and both are joined to each other in an inseparable bond or union where one is incomplete without the other. Each enjoys its ontological status, but morality becomes the parameter for measuring the value of any type of African music. Little wonder morality is an inseparable handmaid of African music.

\section{References}

Achike, C. M. (2011). Liturgy and Church Music. Unizik Journal of Arts and Humanities, 2, 75-92.

Ade-Adegbola, E. A. (1983). Traditional Religion in West Africa. Ibadan: Daystar.

Agordoh, A. A. (1985). Topics in African Music. Obiaruku: C. Y. Publishing House.

Agu, D. C. C. (2001). The Impact of Western Education on Traditional Music Creation: Expression and Appreciation in Nigerian Culture. Unizik Journal of Arts and Humanities, 2, 2002-2225.

Asigbo, A. (2012). Re-Inventing the Wisdom of the Ancients: Moral Signposts in Mike Ejiagh's Akuko N'Egwu. In A. B. C. Chiegboka, I. Okodo, \& I. L. Umeanoluue (Eds.), A Bountiful Harvest. Festschrift in Honour of Very Rev. Msgr. Prof. J. P. C. Nzomiwu (pp. 681-690). Nimo: Rex Charles and Patrick.

Basden, G. T. (1966). Among the Ibos of Nigeria. London: Frank Cass.

Cesaire, A. (1972). Discourse on Colonialism. New York: International Review.

Degmecic, D., Pozgain, I., \& Filakov, P. (2005). Music as Therapy. International Review of the Aesthetics of Sociology of Music, 2, 201-232.

Mbiti, J. S. (1975). Introduction to African religion. London: Heinemann.

Mbiti, J. S. (1985). African Religion and Philosophy. London: Heinemann.

Moore, C. (1982). Fela Fela: The beach of a life. London: Alison and Busby.

Nettle, B. (1956). Music in Primitive Culture. London: Cambridge University.

Nketia, J. H. K. (1975). The Music of Africa. London: Oxford University.

Nwala, T. U. (1985). Igbo Philosophy. Lagos: Literanmmed.

Nwamara, A. O. (2009). Music in a Ten Year Democratic Society: An Appraisal of the Nigerian Situation. In A. B. C. Chiegboka, C. E. Nwadigwe, \& E. C. Umezinwa (Eds.), The Humanities and Nigeria's Democratic Experience (pp. 517-535). Nimo: Rex Charles and Patrick.

Onyiuke, Y. S. (2001). Music as a Source of Aesthetic Education. Journal of Arts and Humanities, 2, 45-56.

Soyinka, W. (1976). The Writer in a Modern African State. Transition, 12-13. 